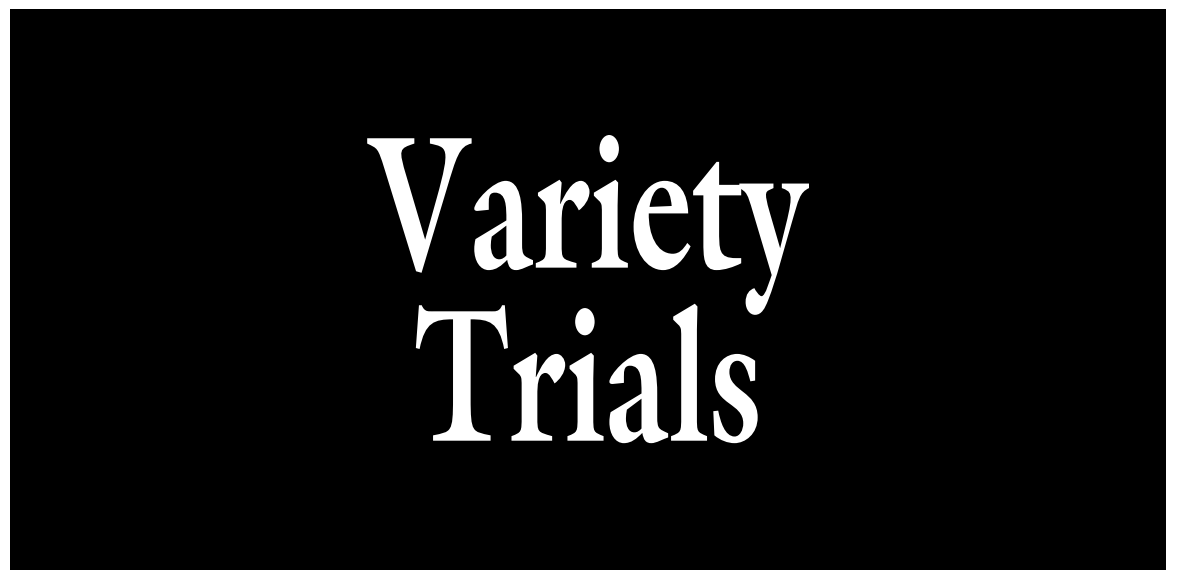

\title{
Vegetable Amaranths for Summer Greens Production in the Northeastern United States
}

\author{
Sarah R. Schweig and Rebecca N. Brown ${ }^{1}$
}

AdDitional InDEX wORDs. ethnic crops, variety trials, plasticulture, Amaranthus

Summary. In 2016, 10 vegetable amaranth (Amaranthus sp.) varieties were evaluated for fresh greens production in the northeastern temperate climate. Yield, $\mathrm{CV}$, and leaf-to-stem ratios were reported for the eight varieties of edible amaranth (Amaranthus tricolor), one of slender amaranth (Amaranthus viridis), and one of green amaranth (Amaranthus bybridus). All plants were grown using drip irrigation and black plastic mulch under 0.8 -mil clear slitted low tunnels. Ten plants of each variety were tested in a randomized complete block design with four replications; the study was repeated seven times over the season, but the seventh planting was excluded from analyses because of frost damage. There was a significant interaction of planting date and variety on yield $(P<0.001)$, but some varieties were consistently high yielding. 'Green Pointed Leaf' and 'Miriah' had the greatest yields overall, did not differ significantly from the highest yielding varieties in any planting, and were notably high yielding in early- and late-season plantings. The effect of variety on yield was reduced in the high ambient temperatures of midsummer. 'Green Callaloo' was high yielding with poor leaf-to-stem ratio; a dwarf variety, 'White Leaf', was low yielding but excelled in leaf-to-stem ratio. 'Red Callaloo' and 'Red Garnet' had consistently low yields, and generally low but variable leaf-to-stem ratios. Production and marketing strategies to be considered in addition to performance measures are discussed.

A $s$ the U.S. population increases in cultural diversity, the market for traditional ethnic produce is expanding (Ballenger and Blaylock, 2003). Small farms with flexible, diversified cropping systems are ideally positioned to produce these crops and engage with this market (Mangan et al., 2008). Amaranth is a traditional leaf vegetable in more than 50 countries worldwide, is high in nutritional value, and is regarded as easy to grow and resilient (National Research Council, 2006). As an alternative summer green, amaranth may offer wide familiarity to many regular buyers of ethnic produce, an appealing option for healthconscious buyers of novel produce, and a low-maintenance addition to small farms seeking sustainability through diversified production.

Ethnic crop production and marketing studies in the northeastern United States have found that ethnic produce consumers are eager to buy more of their traditional produce locally. The advantages of engagement with this market can outweigh the production challenges of growing heat-loving crops in the northeastern temperate climate (Govindasamy et al., 2006, 2007; Mangan et al., 2008; Sciarappa et al., 2016). Amaranth leaves, which are featured in a range of traditional Asian, Latino, and African cuisines, are especially sensitive to temperature and low relative humidity, making long-distance shipping challenging (Wheeler et al., 2015). Competition from imports is therefore minimal, and amaranth is a strong candidate for fresh, direct-toconsumer sale.

In New England, the percentage of farms that engage in direct-toconsumer sales and the proportional contribution of these sales to the total agriculture market are roughly five times that of the United States as a whole (U.S. Department of Agriculture, 2012). In these direct-sale systems, growers engage with customers who tend to value both variety and high nutritional value (Bond et al., 2009). Amaranth leaves are high in protein, $\beta$-carotene, iron, calcium, vitamin $\mathrm{C}$, and folic acid (Achigan-Dako et al., 2014). Amaranth leaves have also been rated comparably to spinach (Spinacia oleracea) in sensory evaluations (Abbott and Campbell, 1982). They may therefore lend well to marketing as a substitute for more common greens, even for customers who do not regularly buy ethnic produce.

In addition to niche market access, diversified production is important to mitigating risk for many small farmers (Sassenrath et al., 2010). Amaranth has been reported to be resistant to many biotic and abiotic stresses, so its production in a diversified small farming system could contribute to farm resilience and sustainability. However, region-specific production protocols and variety recommendations are necessary for growers to realize these potential benefits. Like many ethnic crops, amaranth may be unfamiliar to

\begin{tabular}{llll}
\hline $\begin{array}{l}\text { Units } \\
\text { To convert U.S. to SI, } \\
\text { multiply by }\end{array}$ & U.S. unit & SI unit & $\begin{array}{l}\text { To convert SI to U.S., } \\
\text { multiply by }\end{array}$ \\
\hline 0.3048 & $\mathrm{ft}$ & $\mathrm{m}$ & 3.2808 \\
2.54 & inch $(\mathrm{es})$ & $\mathrm{cm}$ & 0.3937 \\
0.4536 & $\mathrm{lb}$ & $\mathrm{kg}$ & 2.2046 \\
1.1209 & $\mathrm{lb} / \mathrm{acre}$ & $\mathrm{kg} \cdot \mathrm{ha}^{-1}$ & 0.8922 \\
0.0254 & $\mathrm{mil}$ & $\mathrm{mm}$ & 39.3701 \\
$\left({ }^{\circ} \mathrm{F}-32\right) \div 1.8$ & ${ }^{\circ} \mathrm{F}$ & ${ }^{\circ} \mathrm{C}$ & $\left({ }^{\circ} \mathrm{C} \times 1.8\right)+32$
\end{tabular}


growers and is understudied for intensive production (Mangan et al., 2008; Sciarappa et al., 2016).

Amaranth has a C4 photosynthetic pathway that allows efficient use of $\mathrm{CO}_{2}$ under moisture and heat stress (Stallknecht and SchulzSchaeffer, 1993). Consequently, its culture will differ significantly from spring and fall greens. Popular vegetable amaranth species thrive in temperatures up to $40{ }^{\circ} \mathrm{C}\left(104.0{ }^{\circ} \mathrm{F}\right)$, do not tolerate temperature below $15^{\circ} \mathrm{C}$ $\left(59.0{ }^{\circ} \mathrm{F}\right)$, and have substantially higher light saturation points than familiar greens such as lettuce ( $L a c$ tuca sativa) and spinach (Ebert et al., 2011). When producing heat-loving crops in the northeastern United States, growers rely on practices that have not been well studied for amaranth production. For example, some growers' guides suggest that not all amaranth species tolerate transplanting (Ebert et al., 2011), but no primary studies on transplant response have been conducted. Black plastic mulch and drip irrigation have been used successfully for amaranth production (Meyers et al., 2001; Sciarappa et al., 2016), but the use of crop covers has not yet been studied.

Traditional amaranth production practices vary around the world and fundamental intensive production practices are not well established. The existing pool of amaranth production literature comprises a wide range of varieties, belonging to at least seven distinct species, studied in varied climates. Plant spacings for amaranth are highly dependent on production system and vary widely. Single harvest and multiple methods of repeat harvest are common in traditional practice, and harvest methodology is not standardized in production literature. Amaranth is often direct seeded, but a limited number of studies have used transplanted seedlings (Edomwonyi and Opeyemi, 2009; Makus, 1984; Maynard, 2013).

Many of these fundamental production decisions are dependent on variety selection. Because amaranth thrives in high heat, varieties have been evaluated for summer greens production in the southern United

\footnotetext{
Department of Plant Sciences and Entomology, University of Rhode Island, Kingston, RI 02881

${ }^{1}$ Corresponding author. E-mail: brownreb@uri.edu. https://doi.org/10.21273/HORTTECH03906-17
}

States (Igbokwe et al., 1988; Makus, 1984; Sealy et al., 1990; Singh and Whitehead, 1996). However, the growing season (May-August) in Kingston, RI, is characterized by average high temperatures from 70 to $83^{\circ} \mathrm{F}$ and average low temperatures from 45 to $60{ }^{\circ} \mathrm{F}$. Although these conditions may be considered suboptimal for some amaranth varieties, previous evaluations in temperate climates suggest that variety sensitivities to temperature, moisture, and photoperiod vary (Campbell and Abbott, 1982; Wu et al., 2000). Reliance on variety recommendations from warmer climates may not be feasible, and resistance to environmental fluctuation may be an important agronomic trait for amaranth growers in the northeastern United States. Target market should also influence variety selection and production strategies. Amaranth cooking techniques vary with sociocultural background, and desirable traits may be determined by intended use (Achigan-Dako et al., 2014). For example, many traditional cuisines make use of amaranth stems and leaves. However, high leaf yield may be important for marketing as an alternative green in the United States.

This study evaluated 10 vegetable amaranth varieties for fresh greens production in the northeastern temperate climate, with a focus on the realities of regional small farms. Greenhousestarted seedlings were transplanted into a low tunnel system, a strategy commonly used to enhance yields and extend the season of heat-loving crops. Plant performance was observed over seven planting dates spanning the entire 2016 growing season. Yield CV and leaf-to-stem ratios of varieties may be useful descriptive measures for new amaranth growers.

\section{Materials and methods}

RESEARCH SITE. Research was conducted during the 2016 growing season at the University of Rhode Island Greene H. Gardner Agricultural Experiment Station in Kingston, RI. From June to Sept. 2016, average temperatures in Kingston ranged from $66.4^{\circ} \mathrm{F}$ in June $\left(0.6^{\circ} \mathrm{F}\right.$ below average) to $74.1^{\circ} \mathrm{F}$ in August $\left(3.1^{\circ} \mathrm{F}\right.$ above average). The soil type is Bridgehampton silt loam with a $0 \%$ to $3 \%$ slope. Two rows of drip tape were laid 12 inches apart under 1-mil embossed black plastic mulch in 30-inch-wide north-south oriented raised beds. Based on soil test results and findings that amaranth responds well to organic forms of nitrogen (N) (AdeOluwa et al., 2009; Edomwonyi and Opeyemi, 2009; Makinde, 2015), the area was fertilized with organic $5 \mathrm{~N}-1.3 \mathrm{P}-3.3 \mathrm{~K}$ fertilizer (Pro-Gro 5-3-4; North Country Organics, Bradford, VT). The application rate was $50 \mathrm{lb} /$ acre of $\mathrm{N}$ at the time of bed preparation. Vegetable amaranth fertility studies have reported a positive yield response to $\mathrm{N}$ application rates up to $135 \mathrm{~kg} \cdot \mathrm{ha}^{-1}$ (120.4 lb/acre) (Singh and Whitehead, 1996), but Onyango et al. (2012) found that the positive response began to plateau at $20 \mathrm{~kg} \cdot \mathrm{ha}^{-1}$ (17.8 lb/acre) of $\mathrm{N}$. The conservative rate of $\mathrm{N}$ application used for this study reflects a desire to minimize nitrate accumulation and leaching losses and to evaluate varieties for low-input, low-cost commercial production.

VArietiEs. Ten amaranth varieties were included in the study. Most were edible amaranth, the most popular and widely available vegetable amaranth species. Edible amaranth varieties were 'Asia Red', 'Green Pointed Leaf', 'Red Stripe Leaf', 'Southern Red' (Evergreen Seeds, Anaheim, CA), 'Red Garnet', 'White Leaf' (Kitazawa Seed Co., Oakland, CA), 'Miriah', and 'Red Callaloo' (Baker Creek Heirloom Seed Co., Mansfield, MO). 'Green Callaloo' (Baker Creek Heirloom Seed Co.) is a variety of slender amaranth, which is commonly eaten in Caribbean and some African cultures. Members of the African Alliance of Rhode Island (AARI) provided seeds of one heirloom green amaranth population from Burundi, which we called 'Mchicha' (meaning “amaranth" in Swahili). Vegetable amaranths vary in size and appearance, and the selected varieties were chosen to represent a range of growth habits and visual traits. 'White Leaf' is a dwarf variety, with a maximum height of $1.5 \mathrm{ft}$ and a dense, bushy growth habit; most varieties can grow up to $3 \mathrm{ft}$ tall and are moderately branched. Leaf colors range from light green to deep burgundy to variegated red and green.

Culture and Design. All plant material was started from seed in the greenhouse (Table 1). No supplemental light was used, and greenhouse set 
Table 1. Seeding and transplant dates, length of growing period, and cumulative growing degree days (GDD) for seven 2016 vegetable amaranth plantings in Kingston, RI. Harvest maturity was defined by flower bud formation.

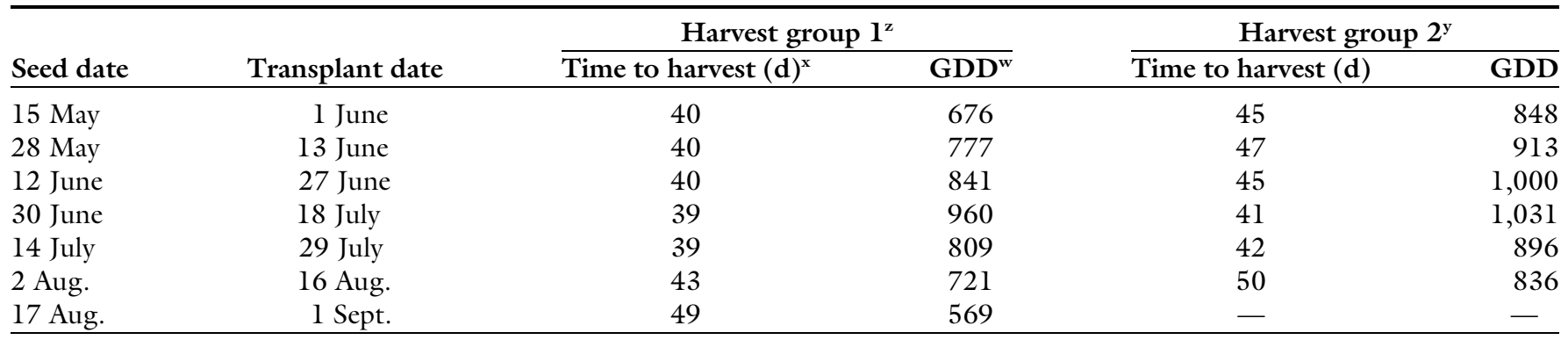

${ }^{z}$ Harvest group 1 varieties were 'Red Garnet', 'Red Callaloo', 'Green Callaloo', 'Miriah', 'Mchicha', 'Red Stripe Leaf', and 'Green Pointed Leaf' .

'Harvest group 2 varieties were 'Asia Red', 'Southern Red', and 'White Leaf'. Frost damage prevented harvest of the seventh planting.

${ }^{\mathrm{x}}$ Accumulated from seeding to harvest.

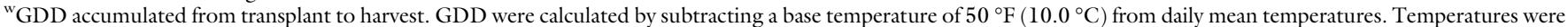
recorded at $25 \mathrm{~cm}$ (9.8 inches) above the soil surface within 0.8 -mil $(0.02 \mathrm{~mm})$ clear slitted low tunnels.

points were $70^{\circ} \mathrm{F}$ (night) and $74^{\circ} \mathrm{F}$ (d). The greenhouse was cooled passively by ventilation, and high temperatures were regularly above the set point. Seeds were planted into 50 -cell trays (cell volume 6.77 inch $^{3}$ ) using a soilless growing medium (MetroMix 830; Sun Gro, Agawam, MA) covered with a thin layer of vermiculite. All varieties were seeded every 2 weeks and transplanted to raised beds at the experiment site roughly 2 weeks later. The first transplanting date was 1 June (daylength about $15 \mathrm{~h}$ ) and the last transplanting date was 1 Sept. (daylength about $13 \mathrm{~h}$ ) (Table $\mathrm{l}$ ). Each experimental plot consisted of 10 plants in two rows, with 12 -inch spacing between and within rows. Plots measured $6 \mathrm{ft} \times 30$ inches and were arranged in a randomized complete block design with four replications.

Directly after transplanting, low tunnels were constructed over the raised beds using galvanized metal hoops and 0.8 -mil clear slitted plastic. Hoops were placed $5 \mathrm{ft}$ apart from each other with a center height of $3 \mathrm{ft}$. Plastic was laid over hoops and staked down at the ends and along the sides of each tunnel. Lastly, a second set of hoops was driven into the ground over the plastic. Sandbags were used to further weigh down plastic on the sides of tunnels during heavy winds. Plots were irrigated as needed, and weeds were controlled by mulching with woodchips between rows and hand-pulling when necessary. Plots were regularly monitored for pests, with the only intervention being a one-time application of pyrethrum (PyGanic; MGK Corp., Minneapolis, MN) to control striped blister beetles (Epicauta vittata) on 14 July.
Harvest. When grown for a single vegetable harvest, whole amaranth plants are commonly pulled from the ground and sold in bundles, including roots (Ebert et al., 2011). Repeated greens harvest is also common and may delay flowering in some species; methods include ratooning (cutting the main stem several inches above the soil) and harvesting individual leaves. To observe flowering behavior, this study used single harvest at the early flowering stage, when first buds were formed (Table 1), similar to the methods used in amaranth variety trials by Campbell and Abbott (1982). Rather than including roots in yield calculations, plants were harvested by cutting directly above the soil surface.

Data Collection AND ANALYsis. Air temperatures within low tunnels were recorded every $4 \mathrm{~h}$ by temperature sensors (iButton; ThermoChron, Lawrenceburg, $\mathrm{KY}$ ) at $25 \mathrm{~cm}$ above the soil surface, approximating mature canopy height. All 10 plants from each plot were weighed together immediately after harvest to determine yield per plot. After fresh weights were recorded, stems and leaves of a random two-plant subsample were separated and dried at $110^{\circ} \mathrm{F}$ until they reached a constant weight. Dried leaf and stem weights were used to calculate a leaf-to-stem ratio, which we expressed as the leaf percentage of total dry weight.

The analysis of variance functions in $\mathrm{R}$ (version 3.2.3; $\mathrm{R}$ Core Team, Vienna, Austria) were used to test for effects and interactions of variety and planting date on both yield and leaf-to-stem ratio. Tukey's honestly significant difference test was used for means separation. All tests were performed at $P<0.05$ significance level. Pearson's test of correlation was used to determine the correlation between fresh weight and leaf-to-stem ratio. Coefficients of variation were calculated as a measure of yield stability.

\section{Results}

GROWTH PERIOD. Using bud formation to define harvest maturity, the varieties clearly split into two distinct groups: 'Red Garnet', 'Red Callaloo', 'Green Callaloo', 'Red Stripe Leaf', 'Miriah', 'Mchicha', and 'Green Pointed Leaf' consistently reached harvest maturity earlier (overall 42 d to harvest) than 'Asia Red', 'Southern Red', and 'White Leaf' (overall 46 $\mathrm{d}$ to harvest) (Table 1 ). An exception to these groupings occurred in the sixth planting; many of the 'Red Garnet' and 'Red Callaloo' stems were broken in a storm, and these varieties were harvested with the second group. Both groups took the longest time to reach harvest maturity in the seventh planting, and plants were frost-damaged before the second group was harvested. Consequently, only results from the first six plantings are included in analyses.

YIELD. There was a significant variety by planting date interaction for yield $(P<0.001)$. Consequently, variety effects were analyzed separately for each planting date (Table 2), and the effect of planting date was analyzed separately for each variety (Fig. 1).

VARIETY EFFECTS. 'Miriah' and 'Green Pointed Leaf' yields were not significantly different in any planting and were the highest in overall averages $(3.10$ and $3.05 \mathrm{~kg} / \mathrm{plot}$, 
Table 2. Effect of variety on vegetable amaranth yields in six planting dates (seeded about 2 weeks apart, from May 2016 to Aug. 2016) in Kingston, RI. Values are means of four replications.

\begin{tabular}{|c|c|c|c|c|c|c|c|}
\hline \multirow[b]{3}{*}{ Variety } & \multicolumn{6}{|c|}{ Yield $(\mathrm{kg} / \text { plot })^{\mathrm{z}}$} & \multirow[b]{3}{*}{ Overall avg } \\
\hline & \multicolumn{6}{|c|}{ Planting date } & \\
\hline & 1 & 2 & 3 & 4 & 5 & 6 & \\
\hline Green Pointed Leaf & $4.09 \mathrm{a}$ & $2.53 \mathrm{a}$ & $2.34 \mathrm{a}$ & $2.98 \mathrm{ab}$ & $2.95 \mathrm{ab}$ & $3.41 \mathrm{abc}$ & 3.05 \\
\hline Mchicha & $1.97 \mathrm{bc}$ & $2.50 \mathrm{a}$ & $2.68 \mathrm{a}$ & $3.27 \mathrm{a}$ & $3.01 \mathrm{a}$ & $3.29 \mathrm{abc}$ & 2.79 \\
\hline Southern Red & $2.40 \mathrm{~b}$ & $2.60 \mathrm{a}$ & $2.66 \mathrm{a}$ & $3.10 \mathrm{ab}$ & $2.88 \mathrm{abc}$ & $2.81 \mathrm{abc}$ & 2.74 \\
\hline Asia Red & $1.43 \mathrm{bc}$ & $1.80 \mathrm{abc}$ & $1.47 \mathrm{bc}$ & $2.65 \mathrm{abc}$ & $2.54 \mathrm{abc}$ & $2.03 \mathrm{abc}$ & 1.99 \\
\hline White Leaf & $1.98 \mathrm{bc}$ & $1.44 \mathrm{bc}$ & $2.18 \mathrm{ab}$ & $1.98 \mathrm{bc}$ & $2.23 \mathrm{abc}$ & $1.93 \mathrm{abc}$ & 1.96 \\
\hline Red Callaloo & $1.38 \mathrm{bc}$ & $1.83 \mathrm{abc}$ & $2.07 \mathrm{abc}$ & $2.25 \mathrm{abc}$ & $1.98 \mathrm{bc}$ & $1.45 \mathrm{c}$ & 1.83 \\
\hline Red Garnet & $1.42 \mathrm{bc}$ & $1.34 \mathrm{c}$ & $2.27 \mathrm{a}$ & $1.61 \mathrm{c}$ & $1.90 \mathrm{c}$ & $2.27 \mathrm{abc}$ & 1.80 \\
\hline
\end{tabular}

${ }^{\mathrm{z}}$ Each plot measured $6 \mathrm{ft} \times 30$ inches $(1.8 \mathrm{~m} \times 76.2 \mathrm{~cm})$ and contained 10 plants; $1 \mathrm{~kg}=2.2046 \mathrm{lb}$.

${ }^{\mathrm{y}}$ Average of six planting dates.

${ }^{\mathrm{x}}$ Two-way analysis of variance showed significant variety by planting date interaction on yield $(P<0.001)$. Tukey's honestly significant difference test was used for separation of variety means within each planting date. Means within a column followed by a common letter are not significantly different at $P<0.05$.

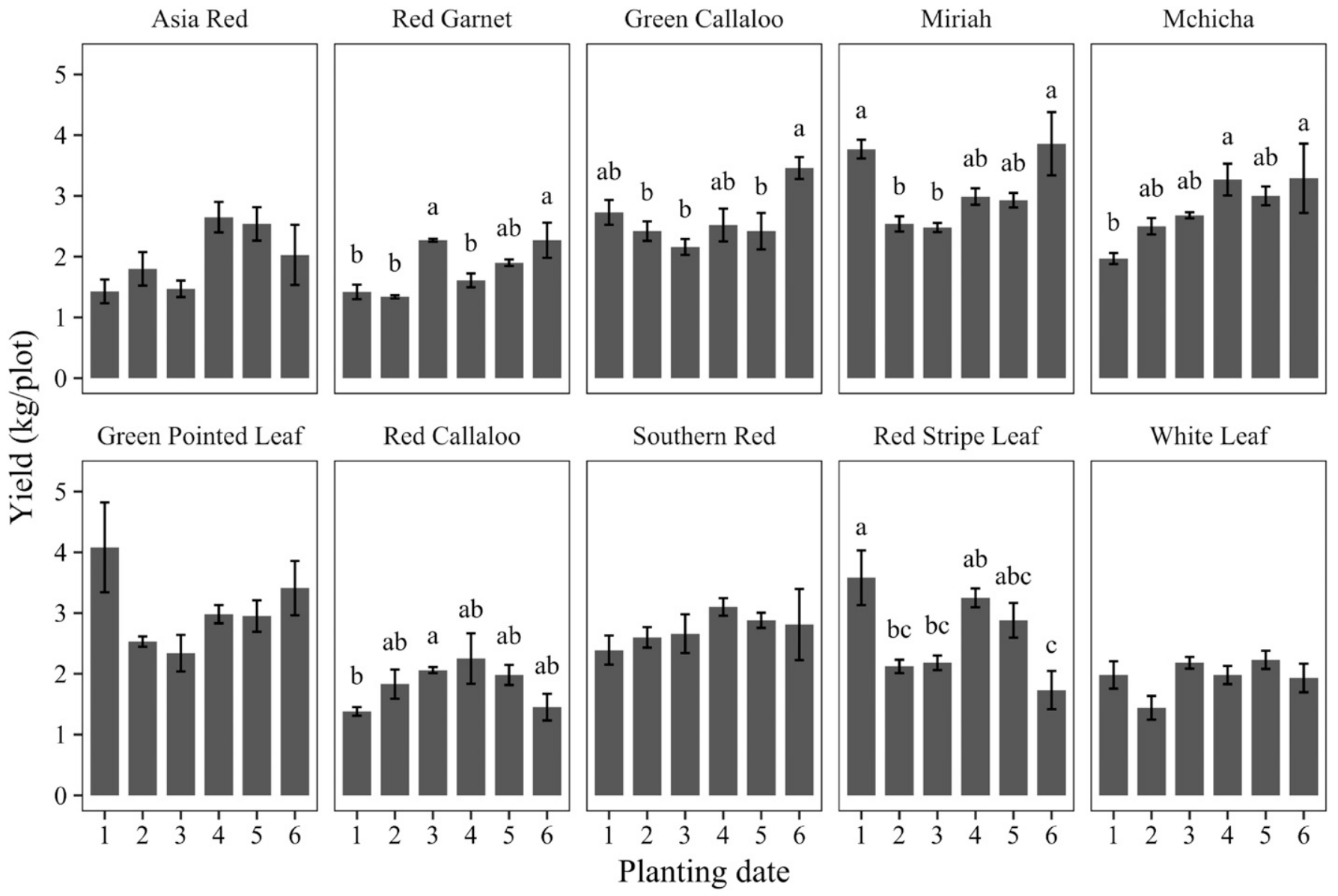

Fig. 1. Effect of planting date on yields of 10 vegetable amaranth varieties. Planting dates were about 2 weeks apart, seeded from May to Aug. 2016 in Kingston, RI. Each plot was $6 \mathrm{ft} \times 30$ inches $(1.8 \mathrm{~m} \times 76.2 \mathrm{~cm})$ and contained 10 plants; values are means of four replications; error bars are \pm SE. Two-way analysis of variance showed significant variety by planting date interaction on yield $(P<\mathbf{0 . 0 0 1})$. Tukey's honestly significant difference test was used for means separation within each variety. Columns with common letters in the same variety are not significantly different at $P<0.05$. Varieties without letters had no significant means separations at $P<0.05 ; 1 \mathrm{~kg}=2.2046 \mathrm{lb}$.

respectively). 'Red Garnet' and 'Red Callaloo' yields were not significantly different in any planting and were the lowest in overall averages $(1.80$ and $1.83 \mathrm{~kg} / \mathrm{plot}$, respectively) (Table 2).
The effect of variety on yield was greatest in the first planting. In the third planting, all varieties except 
'Asia Red' showed no significant differences in yield (Table 2). Except for 'Miriah' yielding significantly more than 'Red Stripe Leaf' in the sixth planting date, there were no significant yield differences between the top-performing varieties ('Miriah', 'Green Pointed Leaf', 'Green Callaloo', 'Southern Red', 'Mchicha', and 'Red Stripe Leaf') in the last five out of the six planting dates (average $2.76 \mathrm{~kg} /$ plot) (Table 2). There was greater variation among these top performers in the first planting, where 'Green Pointed Leaf' yields were significantly greater than 'Southern Red' and 'Mchicha' yields were significantly less than 'Miriah', 'Green Pointed Leaf', and 'Red Stripe Leaf'.

Planting date effects. There was no significant effect of planting date on yield for 'Green Pointed Leaf' $(P=0.14)$, 'Southern Red' $(P=0.67)$, or 'White Leaf' $(P=0.08)$. The planting date effect for 'Red Callaloo' yields was minimally significant $(P=0.05)$ (Fig. 1). Combined average yields for all varieties were greatest in the fourth, fifth, and sixth plantings and lowest in the second planting.

LEAF-TO-STEM RATio. There was a significant variety by planting date interaction on leaf-to-stem ratio $(P<$ $0.001)$. Yield and leaf-to-stem ratio were not correlated $(r=0.036)$. 'White Leaf' was a stand-out performer in leaf-to-stem ratio (average $82 \%)$ and had the greatest leaf-to-stem ratio in all plantings (Fig. 2). 'Asia Red' and 'Miriah' had the second and third highest average leaf-to-stem ratios $(70 \%$ and $69 \%$, respectively) (Fig. 2). 'Red Garnet', 'Red Callaloo', and 'Green Callaloo' consistently had the lowest leaf-to-stem ratios (combined average $45 \%$ ). In the first five plantings, all three had significantly lower leaf-to-stem ratios than most of the varieties tested (Fig. 2).

There was no significant effect of planting date on leaf-to-stem ratio for 'Green Callaloo', 'Mchicha', 'Southern Red', or 'Red Stripe Leaf'. The range of all-season average leaf-tostem ratios was $42 \%$ ('Green Callaloo') to $82 \%$ ('White Leaf').

'White Leaf' had the lowest $\mathrm{CV}$ for yield at $21 \%$, followed closely by 'Southern Red' and 'Green Callaloo', both at $22 \%$. 'Asia Red' had the highest CV for yield at $36 \%$ and 'Red Stripe Leaf' had the second highest at $31 \%$. Figure 3 shows the $\mathrm{cv}$ for yield on the

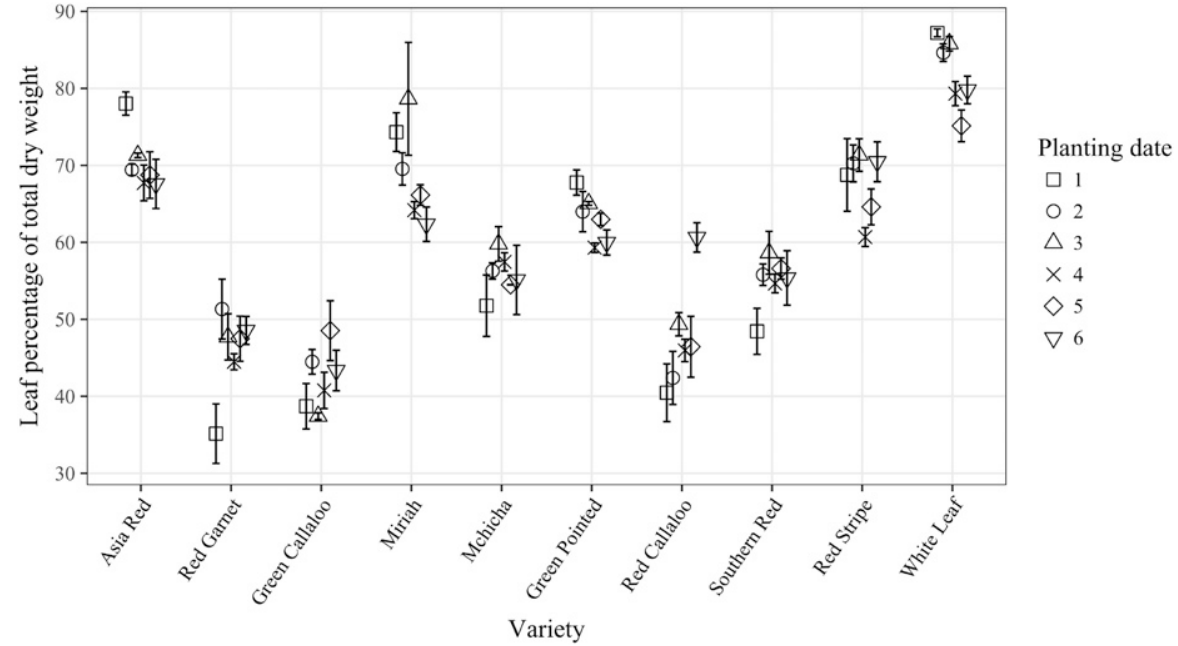

Fig. 2. Leaf-to-stem ratios for 10 vegetable amaranth varieties in six planting dates (seeded about 2 weeks apart, from May 2016 to Aug. 2016) in Kingston, RI. Each plot was $6 \mathrm{ft} \times 30$ inches $(1.8 \mathrm{~m} \times 76.2 \mathrm{~cm})$ and contained 10 plants; values are means of four replications, each represented by a two-plant subsample; error bars are \pm SE.

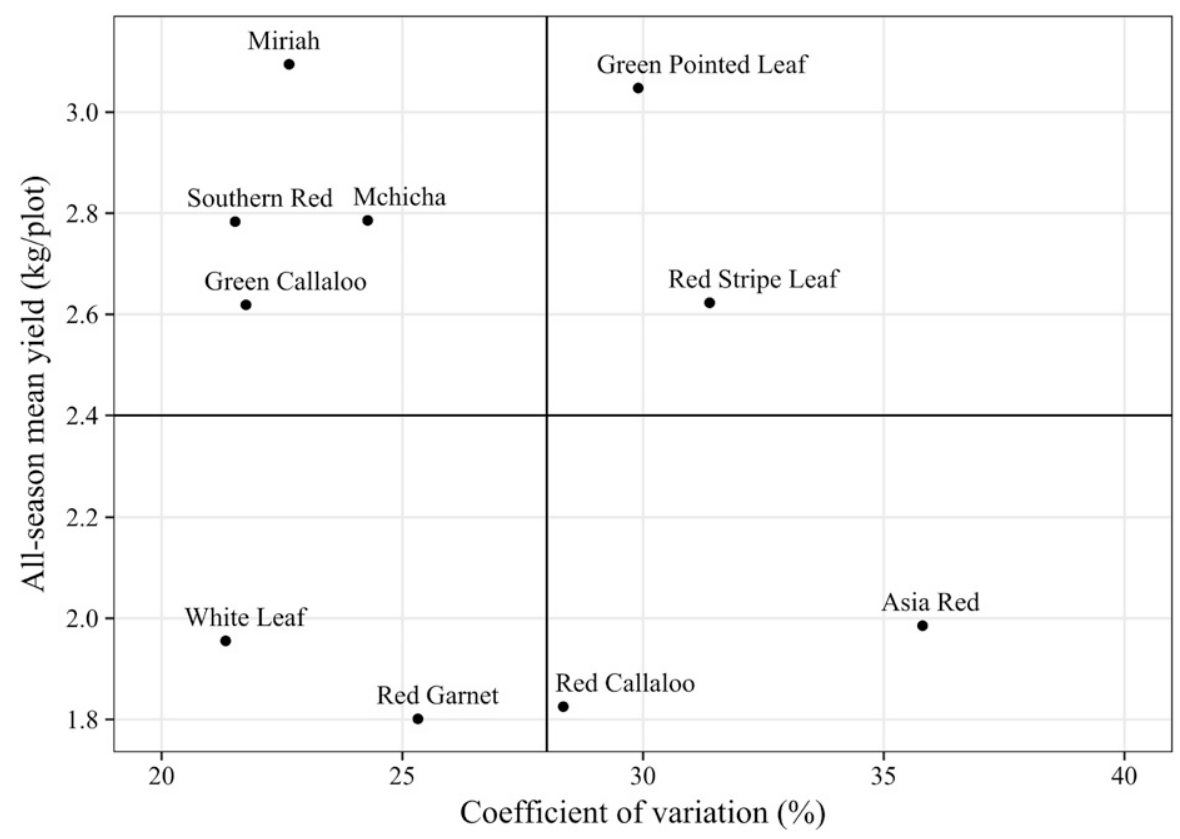

Fig. 3. Yields and cv for yield of 10 vegetable amaranth varieties in Kingston, RI. All-season mean yields and $\mathrm{CV}$ determined using data from six planting dates (seeded about 2 weeks apart, from May 2016 to Aug. 2016), each with four replications. Each plot was $6 \mathrm{ft} \times 30$ inches $(1.8 \mathrm{~m} \times 76.2 \mathrm{~cm})$ and contained 10 plants; $1 \mathrm{~kg}=2.2046 \mathrm{lb}$.

$\mathrm{x}$-axis with grand mean yield on the $\mathrm{y}$-axis. The varieties in the upper left quadrant of Fig. 3 ('Miriah', 'Southern Red', 'Mchicha', and 'Green Callaloo') are those with both low $\mathrm{CV}$ values and high yields.

\section{Discussion}

YIELD FINDINGS COMPARISONS. Because of the relative shortage of variety-level vegetable amaranth production literature, comparison of these results to previous studies requires consideration of the climate and methodology of each study. These results can be most directly compared with those of Maynard (2013), who tested some of the same varieties ('Asia Red', 'Green Pointed Leaf', 'Red Stripe Leaf', and 'White 
Leaf') in a comparable climate in Connecticut. Although Maynard (2013) harvested multiple times rather than once, our findings that 'White Leaf' consistently yielded significantly less than most other varieties confirm those of Maynard (2013). In this study and in reports by Maynard (2013), 'Asia Red' yields were moderate overall and highly variable across plantings. Our findings also compare favorably with those of Maynard (2013) in some top-yielding varieties: 'Green Pointed Leaf' produced greater yields overall than 'Red Stripe Leaf', but yields were not significantly different in any planting. Maynard (2013) found that 'Red Stripe Leaf' yielded more than 'Green Pointed Leaf' in all plantings at two locations, but the yields also showed no significant difference.

All of the varieties evaluated by Maynard (2013) and 8 of the 10 varieties in this study were edible amaranth, which is the most studied vegetable amaranth species and contains the most developed varieties. 'Mchicha' and 'Green Callaloo' have not been included in previous studies, but some useful patterns can be observed in previous evaluations of their respective species. 'Mchicha,' provided by AARI, had the third highest overall average yield in this study $(2.79 \mathrm{~kg} / \mathrm{plot})$, and green amaranth has been evaluated positively in a range of climates. Green amaranth accessions from Greece were top performers in Mississippi (Igbokwe et al., 1988), Texas (Sealy et al., 1990), and Georgia (Singh and Whitehead, 1996), climates that are markedly warmer than that of Rhode Island. In a comparison of amaranths in tropical and temperate regions of China, green amaranth (including 29 accessions) was a top-performing species in the temperate climate of Beijing, at a latitude similar to that of Rhode Island (Wu et al., 2000). These findings would seem to indicate that green amaranth is a strong performer in highly variable climates, but $\mathrm{Wu}$ et al. (2000) suggest that geographic origin of amaranths may be closely linked to response in varying climates. Furthermore, green amaranth is actually defined by high genetic diversity; it is the progenitor of closely related species that have undergone more intense selection
(Achigan-Dako et al., 2014). Although this diversity may well contribute to the broadly positive evaluations of green amaranth, it also makes it somewhat difficult to generalize results pertaining to the species.

'Green Callaloo', the single slender amaranth variety in this study, produced yields that were not significantly different from the top varieties in each planting. Wu et al. (2000) also tested three accessions of slender amaranth for comparison in tropical and temperate climates. Slender amaranth was the top-yielding species in the tropical climate, which is not surprising, given the tropical origins of the selected slender amaranth accessions. However, the species was rated highly adaptable and disease resistant in both climates (Wu et al., 2000).

Photothermal CHARACTERISTICS AND YIELD. Daylength sensitivity in amaranth is not well understood. There are mixed reports of daylength requirements, and the magnitude of daylength sensitivity may be influenced by other environmental factors and cultural practices (Achigan-Dako et al., 2014; Holm et al., 1997; Kulakow and Jain, 1985; Roberts and Summerfield, 1987). Wu et al. (2000) observed that the amaranth populations represented in this study (slender amaranths, edible amaranths, and African populations of green amaranth) all had greater variation in mean growth period in temperate climates than in tropical. Our range of days to harvest, determined by flower bud formation, was 39-43 $\mathrm{d}$ for the first harvest group and 4l$50 \mathrm{~d}$ for the second harvest group (Table 1).

There were significant yield differences within each harvest group in every planting. However, because these varieties represent such a range of growth habits and sizes, dissimilar yields may not exclude similar photothermal responses. There was less variability in flowering time for the first harvest group, yet more significant yield differences across plantings. There was more variability in days to harvest for the second harvest group, yet the yields of these varieties were unaffected by planting date. It is possible that flowering for the second harvest group may be closely linked to plant growth, and given the especially long growth period in the sixth planting, it is possible that the contribution of accumulated daylight hours to growth rate is greater in these varieties. All varieties formed flower buds and were harvested in the first six plantings, indicating that none have an obligate critical daylength outside of about $12 \mathrm{~h}$ (daylength at sixth harvest) and about 15 $h$ (daylength at first harvest).

Performance measures. Although average yield influences $\mathrm{CV}$, consideration of both yield and $\mathrm{CV}$ may be most useful in evaluating variety performance. Leaf-to-stem ratio is a valuable variety descriptor, although it cannot stand alone as a measure of variety desirability. For the most accurate variety assessment, yield, CV, and leaf-to-stem ratio should all be weighed against one another; for ideal variety selection, production strategy and target customer base may play an equal role.

Variety CVs are an indicator of sensitivity to environmental conditions. This may be an important consideration for growers in the northeastern United States, where in comparison with warmer climates, a greater range of temperatures is seen in a shorter growing season. Yield stability across environments could be similarly valuable on new or small-scale farms where soil characteristics and quality are not homogenous. As a measure of variance across all planting dates and replications, the cVs reported here reflect sensitivity to the unique microclimate conditions of each plot location and planting date combination. Where environmental fluctuation is expected, $\mathrm{CV}$ can be useful in avoiding an artificially high estimation of varieties that exhibit high yield potential, rather than reliably high yields.

'Green Pointed Leaf' was one of the two highest yielding varieties over all but had a relatively high $\mathrm{CV}$, indicating that yields are sensitive to microclimate effects (Fig. 3). 'Green Pointed Leaf' yield differences between plantings were not significant, so 'Green Pointed Leaf' may be particularly sensitive to soil quality. Determining which elements of soil quality influenced the yield response is outside the scope of this study. However, this sensitivity could have application for growers when determining soil amendment rates. Individual plot yields for 'Green Pointed 
Leaf' ranged from 1.65 to $5.32 \mathrm{~kg}$, and only one plot over the entire season yielded less than $2 \mathrm{~kg}$. 'Green Pointed Leaf' yields were highest in the first planting $(4.09 \mathrm{~kg} / \mathrm{plot})$, when $50 \%$ of the varieties had their lowest yields of the experiment. Although 'Green Pointed Leaf' yields in the third planting were only $57 \%$ of those in the first planting, yields were comparable to those of the highest yielding varieties on all planting dates. In short, 'Green Pointed Leaf' yields were strong throughout the season, despite high variability. In this case, a high $\mathrm{CV}$ indicates that this strong performer has potential for even higher yields in response to more intensive management.

'Miriah', 'Mchicha', 'Southern Red', and 'Green Callaloo' all had high yields with low Cvs, indicating they are likely desirable varieties (Fig. $3)$. However, 'Green Callaloo' and 'Southern Red' both had low leaf-tostem ratios $(42 \%$ and $55 \%$, respectively), which may be considered less desirable from a product quality perspective (Fig. 2). Campbell and Abbott (1982) found that leaf-tostem ratio was negatively correlated to yield; i.e., varieties with the highest fresh weights tended to be the most stem-heavy. For the varieties tested here, no relationship between leaf-tostem ratio and yield was observed $\left(r^{2}=0.0013\right)$, but 'Red Callaloo' and 'Red Garnet' had the lowest average leaf-to-stem ratios and the lowest average yields overall.

Production strategies and INTENDED MARKeT. Production strategy was standardized in this study for ease of comparison. However, targeted production strategies for individual varieties could positively influence plant performance. In addition, quantitative performance may be qualified by intended market and use. For example, 'White Leaf' had average yields that were around $60 \%$ of the highest yielding varieties. However, 'White Leaf' is a dwarf variety, so these relatively low yields are expected. 'White Leaf' also had the lowest $\mathrm{Cv}$ of all varieties tested (21\%), indicating highly stable yields. Higher yield per production area could be achieved by exploiting 'White Leaf's compact growth habit in higher planting densities than those used in this study. 'White Leaf' had the greatest leaf-to-stem ratio by far $(82 \%)$, which may be as important as total yield if marketing amaranths as substitutes for common greens in the United States.

By contrast, the slender amaranth variety 'Green Callaloo' produced reliably high yields but had the lowest average leaf-to-stem ratio of all varieties tested $(42 \%)$. However, leaf-to-stem ratio has been manipulated through harvesting method in amaranth species with similar growth habits. Oluoch et al. (2009) found that frequent harvests, combined with topping, significantly increased leaf yield for spleen amaranth (Amaranthus dubius), prince's feather amaranth (Amaranthus hypochondriacus), and red amaranth (Amaranthus cruentus). Furthermore, some consumers may place less emphasis on leaf-to-stem ratio. The Caribbean dish callaloo is typically made with slender amaranth and is one of many traditional dishes that cook amaranth stems along with leaves.

The fact that Maynard (2013) reported high yields from 'Red Stripe Leaf' and 'Green Pointed Leaf' with repeat harvest, as did we with single harvest, indicates that growers could opt for either strategy with these varieties. 'Green Pointed Leaf', 'Miriah', and 'Red Stripe Leaf' had the highest leaf-to-stem ratios after 'White Leaf'. Smaller leaves obtained from frequent repeat harvests could be marketed as raw greens, or more mature leaves as cooked greens substitutes.

VARIETY RECOMMENDATIONS. Average yields across varieties were most similar in the third planting. Compared with the average of the second through fifth plantings, the mean square of variety differences was around five times greater in the first planting and about 3.5 times greater in the sixth planting. These trends suggest that variety selection becomes less important for yield in the hottest summer months in the northeastern United States. Growers in the northeastern United States may want to select from the following recommended varieties based on perceived customer preferences, be they cultural or aesthetic. 'Green Callaloo' is a highyielding, reliable variety for which we recommend repeat harvest to improve leaf-to-stem ratio. 'Miriah' and 'Red Stripe Leaf' both have striking flashes of red on their leaves, which is one of the more common and recognizable appearances of edible amaranth. Both were among the highest yielding varieties and had similar leaf-to-stem ratios. Visually, these two varieties are nearly indistinguishable, and both may be especially aesthetically appealing to customers who are unfamiliar with amaranth. 'White Leaf' is reliable and leafy, and increased planting density can balance lower yields per plant. Our findings that the top-yielding varieties in the more variable first and last plantings were also high performers all season make 'Miriah' and 'Green Pointed Leaf' clear choices for a long, productive season in the northeastern temperate climate. Although 'Mchicha' is not a commercially available variety, our findings suggest that further investigation and development of green amaranth varieties may also be promising.

\section{Literature cited}

Abbott, J.A. and T.A. Campbell. 1982. Sensory evaluation of vegetable amaranth (Amaranthus spp.). HortScience 17:409410.

Achigan-Dako, E.G., O.E.D. Sogbohossou, and P. Maundu. 2014. Current knowledge on Amaranthus spp.: Research avenues for improved nutritional value and yield in leafy amaranths in sub-Saharan Africa. Euphytica 197(3):303-317.

AdeOluwa, O.O., G.O. Adeoye, and S.A. Yusuff. 2009. Effects of organic nitrogen fortifiers on some growth parameters of green amaranths (Amaranthus caudatus L.). Renew. Agr. Food Syst. 24(4):245250.

Ballenger, N. and J.R. Blaylock. 2003. Consumer-driven agriculture: Changing U.S. demographics influence eating habits. Amber Waves 1(2):28-33.

Bond, J.K., D. Thilmany, and C. Bond. 2009. What influences consumer choice of fresh produce purchase location? J. Agr. Appl. Econ. 41(1):61-74.

Campbell, T.A. and J.A. Abbott. 1982. Field evaluation of vegetable amaranth (Amaranthus spp.). HortScience 17:407-409.

Ebert, A.W., T. Wu, and S. Wang. 2011. International cooperators' guide-Vegetable amaranth (Amaranthus L.). AVRDC World Veg. Ctr. Publ. No. 11-754.

Edomwonyi, K. and S. Opeyemi. 2009. Growth and yield performance of Amaranthus cruentus influenced by planting density and poultry manure application. Not. Bot. Hort. Agrobot. Cluj-Napoca 37(1):195-199.

Govindasamy, R., A. Nemana, V. Puduri, K. Pappas, B. Schilling, J.E. Simon, 
R. Van Vranken, and L. Brown. 2006. Demographics and the marketing of Asian ethnic produce in the mid-Atlantic states. New Jersey Agr. Expt. Sta. Rpt. No. P-029031-06.

Govindasamy, R., W. Sciarappa, V.S. Puduri, R. Van Vranken, A. Ayeni, K. Pappas, J.E. Simon, F. Mangan, M. Lamberts, and G. McAvoy. 2007. A market driven approach to ethnic crop production for the US east coast, p. 261-273. In: J. Janick and A. Whipskey (eds.). Issues in new crops and new uses. ASHS Press, Alexandria, VA.

Holm, L., J. Doll, E. Holm, J. Pancho, and J. Herberger. 1997. Amaranthus retroflexus L. and Amaranthus viridis L.: Physiology and morphology, p. 60-62. In: L. Holm (ed.). World weeds: Natural histories and distribution. Wiley, New York, NY.

Igbokwe, P.E., S.C. Tiwari, J.B. Collings, J.B. Tartt, and L.C. Russell. 1988. Amaranth: A potential crop for southwestern Mississippi. Res. Rpt.-Mississippi Agr. For. Expt. Sta. 13(5).

Kulakow, P.A. and S.K. Jain. 1985. The inheritance of flowering time in Amaranthus species. J. Genet. 64(2$3): 85-100$.

Makinde, E.A. 2015. Effects of fertilizer source on growth and cumulative yield of Amaranthus. Intl. J. Veg. Sci. 21(2):167176.

Makus, D.J. 1984. Evaluation of amaranth as a potential greens crop in the mid-south. HortScience 19:881-883.

Mangan, F.X., R.U. de Mendonca, M. Moreira, S.d. Nunes, F.L. Finger, Z.d. Barros, H. Galvao, G.C. Almeida, R.A.N. Silva, and M.D. Anderson. 2008. Production and marketing of vegetables for the ethnic markets in the United States. Hort. Bras. 26(1):6-14.
Maynard, A.A. 2013. Vegetable amaranth trials 2008-2010. Connecticut Agr. Expt. Sta. Bul. 1038 .

Meyers, R.D., S. Tubene, M. Spicknall, and A. Hawkins. 2001. Ethnic vegetable production trials on a plasticulture system for the development of an ethnic food market in southern Maryland. Univ. Maryland Coop. Ext., Glen Burnie, MD.

National Research Council. 2006. Amaranth (Amaranthus species), p. 33-51. In: F.R. Ruskin and N.D. Vietmeyer (eds.). Lost crops of Africa: Volume II: Vegetables. Natl. Acad. Press, Washington, DC.

Oluoch, M.O., G.N. Pichop, D. Silué, M.O. Abukutsa-Onyango, M. Diouf, and C.M. Shackleton. 2009. Production and harvesting systems for African indigenous vegetables, p. 145-175. In: C.M. Shackleton, M.W. Pasquini, and A.W Drescher (eds.). African indigenous vegetables in urban agriculture. Earthscan, London, UK.

Onyango, C.M., J. Harbinson, J.K. Imungi, S.S. Shibairo, and O. van Kooten. 2012. Influence of organic and mineral fertilization on germination, leaf nitrogen, nitrate accumulation and yield of vegetable amaranth. J. Plant Nutr. 35(3):342-365.

Roberts, E.H. and R.J. Summerfield. 1987. Measurement and prediction of flowering in annual crops, p. 17-50. In: J.G. Atherton (ed.). Manipulation of flowering. Butterworths, London, UK.

Sassenrath, G.F., J.M. Halloran, D. Archer, R.L. Raper, J. Hendrickson, P. Vadas, and J. Hanson. 2010. Drivers impacting the adoption of sustainable agricultural management practices and production systems of the northeast and southeast United States. J. Sustain. Agr. 34(6):680-702.
Sciarappa, W.J., J. Simon, R. Govindasamy, K. Kelley, F. Mangan, S. Zhang, S. Arumugam, P. Nitzsche, R. Van Vranken, S. Komar, A. Ayeni, G. McAvoy, C. Park, W. Reichert, D. Byrnes, Q. Qu, and B. Shilling. 2016. Asian crops overview: Consumer preference and cultivar growth on the east coast of the United States. HortScience 51:1344-1350.

Sealy, R.L., E.L. McWilliams, J. Novak, F. Fong, and C.M. Kenerley. 1990. Vegetable amaranths: Cultivar selection for summer production in the south, $\mathrm{p}$. 396-398. In: J. Janick and J.E. Simon (eds.). Advances in new crops. Timber Press, Portland, OR.

Singh, B.P. and W.F. Whitehead. 1996. Management methods for producing vegetable amaranth, p. 511-515. In: J. Janick (ed.). Progress in new crops. ASHS Press, Arlington, VA.

Stallknecht, G.F. and J.R. SchulzSchaeffer. 1993. Amaranth rediscovered, p. 211-218. In: J. Janick and J.E. Simon (eds.). New crops. Wiley, New York, NY.

U.S. Department of Agriculture. 2012. Census of agriculture highlights: Farmers marketing. 28 June 2017. <https:// www.agcensus.usda.gov/Publications / 2012/Online_Resources/Highlights/ Farmers_Marketing/Highlights_ Farmers_Marketing.pdf $>$.

Wheeler, L., L. Kitinoja, and D.M. Barrett. 2015. Use of insulated covers over product crates to reduce losses in amaranth during shipping delays. Agriculture 5(4):12041223.

Wu, H., M. Sun, S. Yue, H. Sun, Y. Cai, R. Huang, D. Brenner, and H. Corke. 2000. Field evaluation of an Amaranthus genetic resource collection in China. Genet. Resources Crop Evol. 47(1):43-53. 